\title{
Evidence in support of a role for plant-mediated proteolysis in the rumens of grazing animals
}

\author{
A. H. Kingston-Smith*, R. J. Merry, D. K. Leemans, H. Thomas and M. K. Theodorou \\ Department of Plant, Animal and Microbial Science, Institute of Grassland and Environmental Research, Plas Gogerddan, Aberystwyth \\ $S Y 233 E B, U K$
}

(Received 8 September 2003 - Revised 26 August 2004 - Accepted 7 September 2004)

\begin{abstract}
The present work aimed to differentiate between proteolytic activities of plants and micro-organisms during the incubation of grass in cattle rumens. Freshly cut ryegrass was placed in bags of varying permeability and incubated for $16 \mathrm{~h}$ in the rumens of dairy cows that had previously grazed a ryegrass sward, supplemented with $4 \mathrm{~kg}$ dairy concentrate daily. Woven polyester bags ( $50 \mu \mathrm{m}$ pore size) permitted direct access of the micro-organisms and rumen fluid enzymes to the plant material. The polythene was impermeable even to small molecules such as $\mathrm{NH}_{3}$. Dialysis tubing excluded micro-organisms and rumen enzymes/metabolites larger than $10 \mathrm{kDa}$. DM loss was $46.3 \%$ in polyester, $36.2 \%$ in polythene and $38.1 \%$ in dialysis treatments. It is possible that the DM loss within polythene bags occurred due to a solubilisation of plant constituents (e.g. water-soluble carbohydrates) rather than microbial attachment/degradation processes. The final protein content of the herbage residues was not significantly different between treatments. Regardless of bag permeability, over $97 \%$ of the initial protein content was lost during incubations in situ. Electrophoretic separation showed that Rubisco was extensively degraded in herbage residues whereas the membrane-associated, light-harvesting protein remained relatively undegraded. Protease activity was detected in herbage residues and bathing liquids after all incubation in situ treatments. Although rumen fluid contains proteases (possibly of plant and microbial origin), our results suggest that, owing to cell compartmentation, their activity against the proteins of intact plant cells is limited, supporting the view that plant proteases are involved in the degradation of proteins in freshly ingested herbage.
\end{abstract}

Ruminant: Grazing: Fresh forage: Proteolysis: Rubisco

The rapid breakdown of herbage proteins in the rumen and the inefficiency of nitrogen capture by the rumen microbial population are a major cause of $\mathrm{N}$ loss and pollution in pasturebased ruminant agriculture (Siddons et al. 1985; Beever \& Siddons, 1986; Dewhurst et al. 1996). Grazing ruminants ingest large quantities of living plant biomass, and it is widely assumed that the degradation of plant protein is entirely carried out in the rumen by proteolytic rumen micro-organisms (Wallace \& Cotta, 1988; Wallace et al. 1999, 2001). We have put forward an alternative hypothesis that plant proteases perform the initial phase of proteolysis, perhaps in the first few hours after the ingestion of fresh forage (Theodorou et al. 1996; Zhu et al. 1999; Kingston-Smith \& Theodorou, 2000). This is possible because plant cells contain proteases in lytic vacuoles (Feller, 1986; Matile, 1997). Proteases and peptidases are present in significant quantities in mature leaves and are further induced during stress and senescence (Kingston-Smith \& Theodorou, 2000). Leaf cells therefore possess the intrinsic capacity to degrade their own proteins prior to invasion by cellulolytic and other rumen microorganisms. Extensive proteolysis has previously been observed to occur during in vitro incubations of grass or legumes in the presence or absence of rumen micro-organisms (Zhu et al. 1999; Beha et al. 2002; Kingston-Smith et al. 2003a), indicating the potential activity of plant proteases under rumen-like conditions. Further support comes from observations that autoclaving fresh grass resulted in decreased $\mathrm{NH}_{3}$ production (compared with that from fresh grass) during in vitro fermentation (Wallace et al. 2001), and evidence that plant proteases contribute to proteolysis during ensilage (Papadopoulos \& McKersie, 1983). Here, we present data from experiments in which ryegrass was enclosed in bags or membranes of varying porosity that were incubated in the rumen of dairy cows for $16 \mathrm{~h}$. By restricting direct access of rumen micro-organisms to the plant material, it was possible to quantify protein breakdown under the influence of plant and/ or microbial proteases.

\section{Materials and methods}

Experimental animals

Four lactating Holstein $\times$ Friesian cows, grazing perennial ryegrass supplemented with $4 \mathrm{~kg} / \mathrm{d}$ dairy concentrate, crude protein $(\mathrm{N} \times 6.25) ; 24 \%$, and equipped with a $100 \mathrm{~mm}$ diameter rumen cannula, were used for the in situ experiments described later.

\section{Experimental treatments}

Freshly harvested leaves of perennial ryegrass (Lolium perenne cultivar AberElan) were chopped into $1-2 \mathrm{~cm}$ lengths with 
scissors. Aliquots of $3 \mathrm{~g}$ fresh weight were placed directly into bags made from woven polyester (Saatifil polyester, $50 \mu \mathrm{M}$ pore size; Sericol, Industrial Fabrics Division, Broadstairs, Kent, $\mathrm{UK}$; polyester bag treatment), or suspended in $20 \mathrm{ml}$ artificial saliva (McDougall, 1948) and placed in either polythene 'stomacher' bags (70-75 $\mu \mathrm{m}$ thick), cut to $10 \mathrm{~cm} \times 3 \mathrm{~cm}$ and heat-sealed (Sericol 400 stomacher bags; Guest Medical Ltd, Edenbridge, Kent, UK; polythene bag treatment), or lengths of Spectra/Pore dialysis tubing (Spectra/Por CE $10000 \mathrm{Da}$ cut-off; Spectrum Labs, Breda, The Netherlands; dialysis tubing treatment), which were sealed with dialysis clips. Tests were performed to assess the permeability of polythene to the rumen fluid constituents at typical rumen concentrations. Briefly, heat-sealed polythene bags containing $10 \mathrm{ml}$ deionised water were suspended in screw-top bottles containing $50 \mathrm{ml}$ water supplemented with $150 \mathrm{~mm}$-volatile fatty acid (VFA; acetate-propionate-butyrate, $65: 20: 15$ molar proportions), $15 \mathrm{~mm}-\mathrm{NH}_{3}$ or $1.5 \mathrm{mg} / \mathrm{ml}$ protein (bovine serum albumin, fraction V powder; Sigma-Aldrich UK Ltd, Gillingham, Dorset, UK). After $16 \mathrm{~h}$ incubation at $39^{\circ} \mathrm{C}$, the composition of the internal and external solutions was determined in each of three replicate bottles.

Bags made from polythene and dialysis tubing were placed in polyester bags for support during suspension in the rumen. As a negative control, dialysis tubing (also held in a polyester bag) was filled with $20 \mathrm{ml}$ artificial saliva but no grass was added. These approaches are subsequently referred to on a collective basis as 'in situ' and are modifications of the in situ approach for measuring protein and DM digestibility developed by Mehrez \& Ørskov (1977). Two polyester bag assemblies for each treatment were placed in perforated polythene bottles $(11 \mathrm{~cm}$ long $\times 7 \mathrm{~cm}$ diameter) attached to a stainless steel chain and anchored to a hook on the rumen closure bung. At 16.00 hours, the entire assembly was suspended in the rumen of each of four fistulated cows. Preliminary studies had determined that it was necessary to use perforated bottles to provide support and prevent the polythene, and particularly the dialysis bags, from rupturing during incubation in the rumen. Despite this, damage still occurred, and in some cases only one replicate per animal was recovered intact. After $16 \mathrm{~h}$ incubation, the assembly was removed and the herbage residues recovered by straining the fluid through three layers of muslin. The strained liquid was retained and stored at $-20^{\circ} \mathrm{C}$ until analysed for $\mathrm{NH}_{3}$ and VFA content. Herbage residues were placed in sintered funnels and rinsed with $100 \mathrm{ml}$ distilled water. Aliquots of rinsed herbage residues were used to determine DM disappearance, or were stored at $-80^{\circ} \mathrm{C}$ until analysed for protein content.

\section{Biochemical analyses}

VFA and $\mathrm{NH}_{3}$ determinations were performed as described previously by Zhu et al. (1999) on rumen fluid samples taken before and after the incubation of herbage, and on liquid recovered from polythene and dialysis bags. Protein was extracted from freeze-dried fresh herbage or freeze-dried recovered herbage residues that had been rinsed and stored as detailed earlier. Freeze dried powders $(0.2 \mathrm{~g})$ were rehydrated by the addition of $1.5 \mathrm{ml}$ extraction buffer (0.1 M-HEPES, pH 7.5, 2 mM-EDTA, $1 \mathrm{~mm}$-dithiothreitol, $0.1 \%(\mathrm{v} / \mathrm{v})$ Triton X-100) and homogenised with a hand homogeniser (Model Pro 200; ProScientific Inc, Monroe, CT, USA) for $30 \mathrm{~s}$ at full speed. The homogenates were centrifuged at $10000 \mathrm{~g}$ for $10 \mathrm{~min}$, and the protein content of the supernatants was determined (Bradford, 1976). Protease activity in herbage and liquid fractions was determined by azocasein digestion (Morris et al. 1996). Protease activity was expressed in terms of papain unit equivalents, which was calculated with reference to the $\mathrm{A}_{405 \mathrm{~nm}}$ achieved when between 0.05 and 0.5 units of papain (EC 3.4.22.2; Sigma-Aldrich UK Ltd) activity were used in the azocasein assay (Morris et al. 1996), the freeze-dried protein preparation having been previously reconstituted in $0 \cdot 1 \mathrm{M}-\mathrm{HEPES}, \mathrm{pH} 7 \cdot 5$, containing $2 \mathrm{mM}$-EDTA and $1 \mathrm{~mm}$-dithiothreitol. For electrophoretic separation, polypeptides were extracted from $0.2 \mathrm{~g}$ freeze-dried powder according to Mae et al. (1993) prior to separation by denaturing gel electrophoresis on $12.5 \%$ gels (Laemmli, 1970). Gels were stained with Coomassie Brilliant Blue and photographed, and the bands were quantified by densitometry (BioRad GS710 scanning densitometer equipped with Quantity One software; BioRad UK Ltd, Hemel Hempstead, Hertfordshire, UK).

\section{Statistical analysis}

Differences between treatment means were analysed by ANOVA and individual comparisons by weighted Student's $t$ test (Cochran \& Cox, 1957), both with the Genstat package (Genstat for Windows 6th edition; Baird et al. 2002).

\section{Results}

The effect of varying bag porosity on the degradation of fresh forage was assessed. The incubation of grass in artificial saliva contained in a polythene bag was intended to provide a normal rumen temperature but to exclude rumen micro-organisms, enzymes and low-molecular weight metabolites found in rumen fluid. In tests to determine the permeability of polythene to rumen fluid metabolites, the polythene bags were found to be impermeable to protein, $\mathrm{NH}_{3}$, acetate and propionate but weakly permeable to butyrate with an ingress over $16 \mathrm{~h}$ of $2.8 \mu \mathrm{mol}$ butyrate, which equated to $0.4 \%$ of the amount initially present in the external solution.

The measurement of VFA and $\mathrm{NH}_{3}$ in the rumen fluid of these cows indicated that ruminal conditions were typical of grazing animals (Beever et al. 1978; Beever \& Siddons, 1986). The total VFA concentration in the rumen fluid was $115 \mathrm{~mm}$ when the bag assemblies were introduced into the rumen of the cows, and this had increased, within the normal range, to $150 \mathrm{~mm}$ by the time the assemblies were removed $16 \mathrm{~h}$ later. The concentration of $\mathrm{NH}_{3}$ and molar percentages of acetate, propionate and butyrate were unchanged between the start and end of the experiment, being approximately $15 \mathrm{~mm}$ for ammonia and a ratio of 65:20:14 for acetate-propionate-butyrate.

Accumulation of VFA in the bags depended on treatment. After $16 \mathrm{~h}$ incubation, the liquid in the bags made of polythene contained just $22 \%$ of the VFA concentration found in the rumen fluid and was significantly less than that measured in bags made of dialysis tubing (Table 1). Moreover, with $25 \%$ more acetate and $80 \%$ less propionate, the composition of the VFA pool in the polythene was atypical in comparison to that in the liquid recovered from bags made of polyester or dialysis tubing (Table 1). Bags made of dialysis tubing contained at least $80 \%$ of the VFA concentration of the polyester bags regardless of whether or not herbage had been introduced (Table 1). The 
Table 1. DM loss from herbage and volatile fatty acid (VFA) and ammonia concentrations in the liquid samples recovered from the bag treatments after $16 \mathrm{~h}$ incubation in situ

\begin{tabular}{lcccccc}
\hline & & & & \multicolumn{3}{c}{ VFA molar proportions } \\
\cline { 5 - 7 } Treatments & DM loss $(\%)$ & $\mathrm{NH}_{3}(\mathrm{mM})$ & Total VFA $(\mathrm{mm})$ & Acetate & Propionate & Butyrate \\
\hline Polyester & 46.3 & 14.8 & 150.3 & 65.1 & 18.3 & 14.5 \\
Polythene & 36.2 & 2.4 & 33.2 & 81.5 & 3.31 & 15.2 \\
Dialysis + herbage & 38.1 & 15.8 & 122.9 & 60.9 & 20.7 & 14.9 \\
Dialysis - herbage & - & 14.1 & 119.1 & 64.7 & 19.5 & 12.3 \\
SED & 0.85 & 0.99 & 6.52 & 1.63 & 1.54 & 1.78 \\
df & 8 & 12 & 12 & 12 & 12 & 12 \\
$P$ & $<0.001$ & $<0.001$ & $<0.001$ & $<0.001$ & $<0.001$ & 0.381 \\
\hline
\end{tabular}

df, degrees of freedom.

ammonia concentration measured in the liquid recovered from bags made from dialysis tubing was not significantly different from that present in the polyester bag treatment (Table 1). In contrast, bags made from polythene contained $\mathrm{NH}_{3}$ but only at $16 \%$ of that present in the rumen fluid (Table 1).

A loss of DM from herbage was observed for all treatments, but this was significantly $(P \leq 0.001)$ greater in herbage held in polyester bags compared with herbage enclosed in polythene bags or bags made of dialysis tubing (Table 1); there were no significant differences between the latter two treatments.

The total amounts of protein present in either the herbage, the recovered herbage residues or their associated liquids were determined (Table 2). Because of the free movement of rumen fluid in the polyester bag treatment, comparisons were made by basing calculations on $20 \mathrm{ml}$ sample volumes analogous to the volume of liquid used in the bags made from polythene or dialysis tubing. Given the concentrations of protein determined for rumen fluid $(1.5 \mathrm{mg} / \mathrm{ml})$, contamination of the dialysis bag contents with materials originating from the rumen fluid was low; only $0.02 \mathrm{mg}$ protein was recovered inside control dialysis bags containing only artificial saliva (Table 2).

Significant protein loss from introduced herbage was observed with all treatments regardless of bag porosity. Only $2.5 \%$ of the plant protein was recovered in the herbage residues after $16 \mathrm{~h}$ in the rumen from either polythene or polyester bags (Table 2). Differences in the protein contents of the herbage residues from the different treatments were not statistically significant (Table 2). The amounts of protein in the liquids from the various bag treatments were significantly different from each other (Table 2). More protein was recovered in the liquid contained in polythene bags than in the dialysis tubing bag treatments, but both values were significantly lower than the protein content of the rumen fluid (polyester bag treatment).

Fresh herbage, herbage residues and liquid samples recovered after $16 \mathrm{~h}$ incubation in the rumen were assayed for acid proteases typical of the plant vacuole and also for neutral protease activity that might be predicted to have a role in the near-neutral $\mathrm{pH}$ of the rumen environment. Generally, there were no differences in the observed trends in activity distribution due to the $\mathrm{pH}$ of the assay (Table 2). In all treatments, the total (per sample) protease activity for each recovered herbage residue was significantly lower than the total protease activity contained within the fresh herbage (Table 2). It should be noted that because protein concentrations in fresh herbage were higher than those in herbage residues, the protease activity per $\mathrm{mg}$ herbage protein was 2 - to 3 -fold greater in herbage residues than in fresh herbage (Table 2). In the polythene bag treatment, it appeared that protease had been released from the herbage to the liquid during incubation (Table 2) as the sum of

Table 2. Total amounts of protein and protease activity measured at $\mathrm{pH} 5.0$ and $\mathrm{pH} 7.0$ present in $3 \mathrm{~g}$ fresh herbage, and also in the herbage residues and liquid recovered from bag treatments after incubation in situ of $3 \mathrm{~g}$ fresh herbage for $16 \mathrm{~h}$

\begin{tabular}{|c|c|c|c|}
\hline \multirow[b]{2}{*}{ Treatments } & \multirow[b]{2}{*}{ Total protein $(\mathrm{mg})$} & \multicolumn{2}{|c|}{$\begin{array}{c}\text { Protease activity (papain-equiv- } \\
\text { alent units) }\end{array}$} \\
\hline & & $\mathrm{pH} 5.0$ & $\mathrm{pH} 7.0$ \\
\hline Herbage & 9.08 & $6 \cdot 33$ & $4 \cdot 31$ \\
\hline Polyester: herbage residue & 0.21 & 0.73 & 1.24 \\
\hline Polyester: recovered liquid* & $30 \cdot 77$ & $29 \cdot 07$ & 44.09 \\
\hline Polythene: herbage residue & 0.25 & 0.55 & $1 \cdot 32$ \\
\hline Polythene: recovered liquid & $2 \cdot 15$ & $7 \cdot 36$ & $4 \cdot 47$ \\
\hline Dialysis + herbage: residue & 0.42 & 0.64 & 1.40 \\
\hline Dialysis + herbage: liquid & 0.42 & 13.99 & $6 \cdot 87$ \\
\hline Dialysis - herbage: liquid & 0.02 & 0.09 & 0.50 \\
\hline SED & 3.63 & $1 \cdot 367$ & 3.056 \\
\hline df & 22 & 22 & 22 \\
\hline$P$ & $<0.001$ & $<0.001$ & $<0.001$ \\
\hline
\end{tabular}




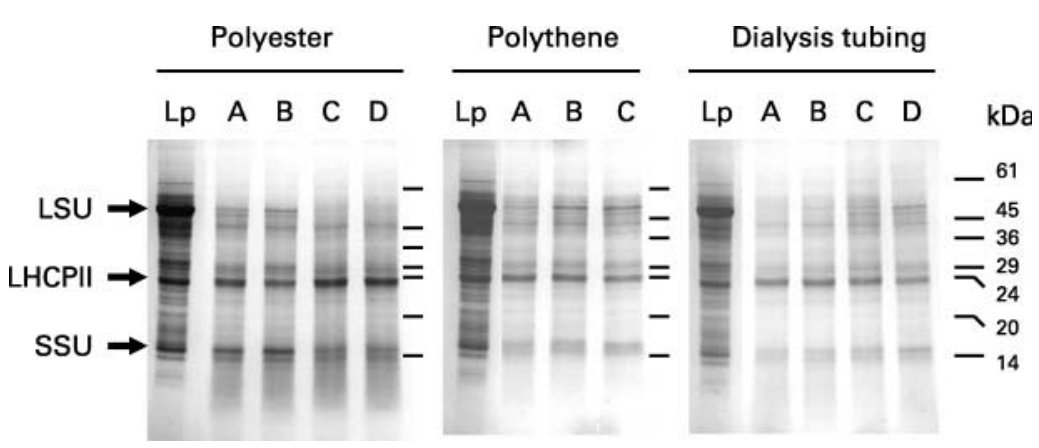

Fig. 1. Polypeptides in ryegrass before and after $16 \mathrm{~h}$ incubation in situ in woven polyester bags, polythene bags or dialysis tubing. Lp, grass before treatment; A$D$, herbage samples recovered from the rumen of four cows ( $A-C$ in the case of the polythene treatment). Molecular weight standards are as indicated on right hand side of the figure. Arrows show Rubisco large and small subunits (LSU, SSU) and light-harvesting complex proteins of photosystem 2 (LHCPII). Gels were loaded with protein extracted from $3 \mathrm{mg}$ DM per track.

protease activity present in the herbage residue plus that in the associated liquid equalled the total activity introduced into each polythene bag as the fresh herbage. Protease activity was also distributed between residue and bathing liquid when the herbage was introduced into dialysis tubing (Table 2), although the total activity recovered in the liquid exceeded that recovered from bags made of polythene. Bags made from dialysis tubing but which lacked herbage were used to assess the level of ingress of rumen fluid proteases; protease activity in the liquid from these bags was negligible compared with rumen fluid activities (Table 2), demonstrating that the dialysis tubing was effective in excluding rumen fluid proteases.

Gel electrophoresis reflected the quantitative changes in protein pools and also revealed compositional alterations in the herbage protein pool as a result of incubation in the rumen (Fig. 1). Although between-animal effects were negligible, there were marked changes in the polypeptide profile in herbage residues from all treatments compared with the polypeptides extracted from fresh herbage (Fig. 1). Gels were loaded on equal DM basis, thus testing the null hypothesis that if there is no proteolysis, band profiles will remain unchanged from those seen with fresh grass. Quantification of polypeptide bands by densitometry revealed differences in the extent of degradation of three major chloroplast polypeptides. Regardless of the treatment, the band densities of the large subunit and small subunit of the most abundant soluble protein, ribulose 1,5 bisphosphate carboxylase/ oxygenase (Rubisco) were significantly lower after $16 \mathrm{~h}$ incubation than they were in fresh herbage (average of $11 \%$ remaining, $P<0.001$ for the large subunit; $56 \%$ remaining, $P=0.002$ for the small subunit). In contrast, bag residues showed no significant change in the density of the polypeptide band corresponding to the membrane-associated protein light-harvesting complex proteins of photosystem 2 (LHCPII).

\section{Discussion}

Theodorou et al. (1996) suggested that plant-mediated proteolysis might play a role in the degradation of herbage proteins in ruminants grazing fresh pastures, and Zhu et al. (1999) subsequently provided in vitro evidence that plant proteases can be active during the digestion of fresh forages. The aim of the work presented here was to use an exclusion system to differentiate between the proteolytic activities of plant and microbial populations during incubation in situ in the rumen.
The treatments described were designed to allow complete access of the micro-organisms to plant material (via pores in the polyester bags), complete exclusion of the rumen microorganisms (via a polythene membrane) or interaction of the rumen metabolites with plant material while preventing the ingress of larger macromolecules, including proteolytic enzymes in rumen fluid (via selective size-exclusion dialysis tubing).

For grass enclosed in polyester bags (pore size of $50 \mu \mathrm{m}$ ), it was assumed that the composition of rumen fluid on both sides of the bag was the same. Meyer \& Mackie (1986) showed that, for pore sizes between 20 and $53 \mu \mathrm{m}$, feed type was a more significant factor than pore size in influencing the composition of the rumen fluid on either side of the polyester bag, but unfortunately these authors did not include fresh forage in their experiments. However, a $53 \mu \mathrm{m}$ pore size was shown to give the least difference in protozoal and bacterial counts either side of polyester bags containing a high-roughage diet (Meyer \& Mackie, 1986). It is therefore likely that normal rumen conditions were simulated in the experiments described here, with rumen micro-organisms, enzymes and metabolites having unrestricted access to the herbage.

The final concentration of VFA and $\mathrm{NH}_{3}$ in the liquid recovered from the polythene bags was less than a quarter of the concentrations typically found in the rumen, whereas the concentrations of these metabolites in the bags made of dialysis tubing were more similar to those of rumen fluid (Table 1). The molar proportions of the VFA in the polythene bag liquids were also atypical of those found in the rumen fluid and dialysis bag liquids. The accumulation of lower concentrations of VFA with atypical molar proportions was also observed in previous research (Zhu et al. 1999), in which ryegrass was incubated in anaerobic buffer in the absence of microorganisms. Together with the porosity studies conducted with polythene, these data indicate that whereas dialysis tubing did not restrict the movement of low-molecular weight rumen components, polythene was an effective barrier to rumen metabolites.

A significant loss of DM was observed in all in situ incubations, but DM degradation was more extensive in polyester bags that had full exposure to rumen micro-organisms than when microbial access was restricted by the enclosure of herbage in either dialysis or polythene bags. Taken collectively, the data for protein and DM losses strongly indicate a process partition, whereby protein and fibre degradation can be partitioned as predominantly plant and microbial activities respectively. This has implications for microbial ecology and the 
efficiency of feed utilisation. As rumen microbial enzymes were unlikely either to penetrate polythene or to cross the dialysis membrane, it is suggested that the DM loss within polythene bags relates to the solubilisation of plant constituents (i.e. water-soluble carbohydrates). Thus, in the present study, a DM loss of approximately $35 \%$ from the incubated herbage is potentially independent of micro-organisms and is due to plant-based processes and activities associated with plant cell death. A similar discrimination of plant- and microbium-based activities pertaining to the release of plant vacuolar contents has previously been demonstrated (Kingston-Smith et al. 2003b).

It is possible that some fermentation took place in the polythene bags during the $16 \mathrm{~h}$ incubation period, presumably facilitated by herbage epiphytic micro-organisms. Strictly anaerobic bacteria of the genus Clostridium are commonly found in manure and on herbage, and can be active in the ensiling process (Pahlow et al. 2003). They can also be isolated as part of the rumen microflora (Stewart et al. 1997). Epiphytic and silage clostridia are sometimes grouped into phenotypically relevant groups, i.e. those that can ferment a variety of carbohydrates (e.g. Clostridium butyricum and $C$. tyrobutyricum) and others that have a limited capacity to ferment carbohydrates, or 'proteolytic' species (e.g. C. sporogenes and C. bifermentans; Pahlow et al. 2003). Butyrate is the major end product of fermentation by carbohydrate-fermenting clostridia, and it was observed that butyrate accumulated in the polythene bags to give similar concentrations to those found in the rumen. It is therefore possible that these micro-organisms could have grown within the bags during incubation and contributed to the observed DM loss via extensive utilisation of the soluble carbohydrate (typically present at about 10-15\% DM; Lee et al. 2001). Likewise, it is possible that plant epiphytic clostridia could have contributed to the observed degradation of protein. Plant epiphytic clostridia are, however, typically found in very low numbers on non-manured forage crops (Buxton \& O'Kiely, 2003), which is comparable with the forage used in the present study, and only a small proportion of these may be proteolytic species. Hence, although butyrate formation in the polythene bag treatment could be attributed, at least in part, to clostridial activity, it is less likely that clostridia would have made a significant contribution to proteolysis during $16 \mathrm{~h}$ in the polythene bag treatments. In this and the previous study by Zhu et al. (1999), although the $\mathrm{NH}_{3}$ in the polythene bag treatment could have arisen as a result of the activity of epiphytic micro-organisms, it is also possible for both acetate and $\mathrm{NH}_{3}$ to be produced in plant cells, acetate by the $\beta$-oxidation of fatty acids, by terpenoid biosynthesis or during fermentation (Roughan, 1995; Nakazono et al. 2000), and $\mathrm{NH}_{3}$ as a result of glutamate dehydrogenase activity (Thomas, 1978, Coruzzi \& Last, 2000).

In comparison to fresh herbage, substantial changes in the protein content and polypeptide profile of incubated residues were observed in all in situ incubations. We observed the differential breakdown of chloroplast proteins in the rumen when these were present in the form in which they exist in planta. Whereas the $55 \mathrm{kDa}$ polypeptide of Rubisco was almost undetectable after $16 \mathrm{~h}$ incubation, the photosynthetic protein LHCPII was still clearly visible. This agrees with previous data from in vitro experimentation (Beha et al. 2002) and confirms previous indications of substrate specificity during ruminal proteolysis when purified plant proteins were supplied (Nugent \& Mangan, 1981; Nugent et al. 1983). It has been suggested that the specificity of degradation is linked to the tertiary structure of the proteins, especially the presence of sulphydryl linkages (Nugent \& Mangan, 1981; Spencer et al. 1981). Given that the final protein profile in our experiments was not affected by the presence or absence of rumen fluid, such a structure-based determination of susceptibility to proteolysis could be caused by proteases of plant origin whereby the specificity in protein degradation is due to the localisation and accessibility of proteolytic target sites within the plant cell. Rubisco is a soluble protein and is present in the chloroplast, whereas LHCPII is integrated within the thylakoid membrane of the chloroplast. Proteolytic activities capable of degrading the Rubisco large subunit have previously been observed in a number of plants and may be localised to the chloroplast (Bushnell et al. 1993; Roulin \& Feller, 1998). In contrast, endogenous proteolytic activity in chloroplasts appears to be ineffective against membrane-integrated LHCPII (Anastassiou \& Argyroudi-Akoyunglou, 1995). LHCPII is one of a number of chlorophyll-binding proteins and it is believed that there is in planta a protective effect derived from the complexing of proteins and chlorophyll (Bennett, 1981; Lindahl et al. 1995; Thomas, 1997). During digestion, it is possible that this complex survives the rumen but that later dissociation permits this chlorophyll to pass through the animal in the form of phaeo-derivatives. It is notable that protein was not totally degraded in these incubations, which is in agreement with previous results from in vitro experiments (Beha et al. 2002).

A comparison of the polythene treatment with the dialysis tubing treatment raises some interesting questions pertaining to the relative roles of plant and microbial proteases. Given that the polythene bag treatment represented a sealed system, it appears that a significant proportion $(25 \%)$ of the protein in the herbage placed in the bag at the start of the experiment leached from the tissue into the surrounding liquid (Table 2). Thus, the difference between, on the one hand, the sum of protein recovered in the herbage residues and their associated liquid fractions in the polythene bag treatment and, on the other, the amount of plant protein introduced in the fresh herbage represents the fraction subject to active degradation by plant proteases. Much less protein was recovered in the liquid from bags made of dialysis tubing than from those made of polythene (Table 2). This is likely to be due to the fact that the proteolytic products were of a sufficiently small size to cross the semi-permeable (size-exclusion) barrier formed by the dialysis tubing. The plant-mediated proteolytic generation of low-molecular weight peptides and amino acids has previously been seen (Zhu et al. 1999; Beha et al. 2002).

It is clear that, during the incubations, plant proteases were lost from the herbage residue but remained active in the liquid contained within polythene bags. Here, and previously (KingstonSmith et al. 2003a), protease activity per mg protein increased in the herbage residues as a result of anaerobic incubation. This implies that the plant proteases were protected from degradation. Taken collectively, the release of proteases from herbage to the liquid phases, and the apparent protection of proteases from degradation, present the opportunity for plant proteases to accumulate and remain active in the rumen fluid; i.e. some of the extracellular protease activity in the rumen is of plant origin. Surprisingly, the protease activity in the liquid fraction from treatments involving dialysis bags exceeded the activity found in fresh herbage by a factor of two (Table 2). This difference cannot be attributed to contamination by proteases from 
the rumen fluid (i.e. to be proteases with a molecular mass $<10 \mathrm{kDa}$ ) as only 0.09 units of protease activity was recovered in the dialysis tubing initially containing artificial saliva. It is possible that a low-molecular weight (dialysable) factor in the rumen fluid could stimulate activity via either the activation of pre-existing protease proteins or the de novo synthesis of proteases. Alternatively, there could be a dialysable inhibitor present in the grass that is retained in the polythene bag treatments but is removed from dialysis bag treatments.

Although the effect of mastication and rumination on tissue damage and the consequent release of plant proteins was not considered in the present work, the results obtained demonstrate that plant protein was degraded to the same extent regardless of accessibility of the micro-organisms to the plant biomass, which clearly shows the importance of obtaining further data relating to the role played by plant and microbial proteases in the initial stages of the degradation of herbage proteins in the rumen.

\section{Acknowledgements}

The authors thank Roger Evans and the ' $D$ ' unit staff for their skilled technical assistance, Dan Dhanoa for his valuable advice regarding the statistical analyses, Dave Thomas for technical support and David Davies for critical reading of the manuscript. Financial support was provided by the Department for Environment, Food and Rural Affairs (DEFRA) and the Biotechnology and Biological Sciences Research Council, UK (BBSRC).

\section{References}

Anastassiou R \& Argyroudi-Akoyunglou JH (1995) Thylakoid-bound activity against LHCII apoprotein in bean. Photosynth Res 43, $241-250$.

Baird DB, Harding SA, Lane PW, Murray DA, Payne RW \& Soutar DM (2002) Genstat for Windows, 6th ed. Oxford: VSN International.

Beever DE \& Siddons RC (1986) Digestion and metabolism in the grazing ruminant. In Control of Digestion and Metabolism in Ruminants. Proceedings of the Sixth International Symposium on Ruminant Physiology held at Banff, Canada, September 10th-14th, 1984, pp. 479-497 [LP Milligan, WL Grovum and A Dobson, editors]. Englewood Cliffs, NJ: Prentice-Hall.

Beever DE, Terry RA, Cammell SB \& Wallace AS (1978) The digestibility of spring and autumn harvested perennial ryegrass by sheep. J Agric Sci 90, 463-470.

Beha EM, Theodorou MK \& Kingston-Smith AH (2002) Grass cells ingested by ruminants undergo autolysis which differs from senescence: implications for grass breeding targets and livestock production. Plant Cell Environ 25, 1299-1312.

Bennett J (1981) Biosynthesis of the light-harvesting chlorophyll $a / b$ binding protein. Peptide turnover in darkness. Eur J Biochem 118, $61-70$.

Bradford MM (1976) A rapid and sensitive method for the quantitation of microgram quantities of protein utilizing the principle of protein-dye binding. Analyt Biochem 72, 248-254.

Bushnell TP, Bushnell D \& Jagendorf AT (1993) A purified zinc-protease of pea chloroplasts, EP1, that degrades the large subunit of ribulose1,5-bisphosphate carboxylase/oxygenase. Plant Physiol 103, 585-591.

Buxton DR \& O'Kiely P (2003) Preharvest plant factors affecting ensiling. In Silage Science and Technology, pp. 199-250 [DR Buxton, RE Muck and JH Harrison, editors]. Agronomy No. 42, Madison, WI: American Society of Agronomy Inc, Crop Science Society of America, Inc, Soil Science Society of America Inc.
Cochran WG \& Cox GM (1957) Experimental Designs, 2nd ed. New York: John Wiley \& Sons.

Coruzzi G \& Last R (2000) Amino acids. In Biochemistry and Molecular Biology of Plants, pp. 358-410 [B Buchanan, W Gruissem and R Jones, editors]. Rockville MD: ASPB.

Dewhurst RJ, Mitton AM, Offer NW \& Thomas C (1996) Effects of the composition of grass silages on milk production and nitrogen utilization by dairy cows. An Sci 62, 25-43.

Feller U (1986) Plant proteolytic enzymes in relation to leaf senescence. In Plant Proteolytic Enzymes, pp. 49-68 [MJ Dalling, editor]. Boca Raton, FL: CRC Press.

Kingston-Smith AH \& Theodorou MK (2000) Post-ingestion metabolism of fresh forage. New Phytol 148, 37-55.

Kingston-Smith AH, Bollard A, Armstead IP, Thomas BJ \& Theodorou MK (2003a) Proteolysis and cell death in clover leaves is induced by grazing. Protoplasma 220, 119-129.

Kingston-Smith AH, Bollard A, Thomas BJ, Brooks AE \& Theodorou MK (2003b) Nutrient availability during the early stages of colonization of fresh forage by rumen micro-organisms. New Phytol 158, 119-130.

Laemmli UK (1970) Cleavage of structural proteins during the assembly of the head of bacteriophage T4. Nature 227, 680-685.

Lee MRF, Jones EL, Moorby JM, Humphreys MO, Theodorou MK, MacRae JC \& Scollan ND (2001) Production responses from lambs grazed on Lolium perenne selected for an elevated water-soluble carbohydrate concentration. Anim Res 50, 441-449.

Lindahl M, Yang DH \& Andersson B (1995) Regulatory proteolysis of the major light-harvesting chlorophyll $\mathrm{a} / \mathrm{b}$ protein of photosystem II by a light-induced membrane associated enzymic system. Eur J Biochem 231, 503-509.

McDougall EI (1948) Studies on ruminant saliva. 1. The composition and output of sheep's saliva. Biochem J 43, 99-109.

Mae T, Thomas H, Gay AP, Makino A \& Hidema J (1993) Leaf development in Lolium temulentum: photosynthesis and photosynthetic proteins in leaves senescing under different irradiances. Plant Cell Physiol 34, 391-399.

Matile P (1997) The vacuole and cell senescence. In The Plant Vacuole, vol. 25, pp. 87-112 [RA Leigh and D Sanders, editors]. Advances in Botanical Research. London: Academic Press.

Mehrez AZ \& Ørskov ER (1977) A study of the artificial fibre bag technique for determining the digestibility of feeds in the rumen. $J$ Agric Sci 88, 645-650.

Meyer JHF \& Mackie RI (1986) Microbiological evaluation of the intraruminal in sacculus digestion technique. Appl Environ Microbiol 51, 622-629.

Morris K, Thomas H \& Rogers L (1996) Endopeptidases during the development and senescence of Lolium temulentum leaves. Phytochem 41, 377-384.

Nakazono M, Tsuji H, Li Y, Saisho D, Arimura S-I, Tsutsumi N \& Hirai A (2000) Expression of a gene encoding mitochondrial aldehyde dehydrogenase in rice increases under submerged conditions. Plant Physiol 124, 587-598.

Nugent JHA, Jones WT, Jordan DJ \& Mangan JL (1983) Rates of proteolysis in the rumen of the soluble proteins casein, fraction 1 (18S) leaf protein, bovine serum albumin and bovine submaxillary mucoprotein. Br J Nutr 50, 357-388.

Nugent JHA \& Mangan JL (1981) Characterisation of the rumen proteolysis of fraction 1 (18S) leaf protein from lucerne (Medicago sativa L.). Br J Nutr 46, 39-58.

Pahlow G, Muck RE, Driehuis F, Oude Elferink, SJWH \& Speolstra SF (2003) Biochemistry of ensiling. In Silage Science and Technology, pp. 31-93 [DR Buxton, RE Muck and JH Harrison, editors]. Agronomy No. 42, Madison, WI: American Society of Agronomy Inc, Crop Science Society of America Inc, Soil Science Society of America Inc.

Papadopoulos YA \& McKersie BD (1983) A comparison of protein degradation during wilting and ensiling of six forage species. Can $J$ Plant Sci 63, 903-912. 
Roughan PG (1995) Acetate concentrations in leaves are sufficient to drive in vivo fatty acid synthesis at maximum rates. Plant Sci 107, 49-55.

Roulin S \& Feller U (1998) Light-independent degradation of stromal proteins in intact chloroplasts isolated from Pisum sativum L. leaves: requirement for divalent cations. Planta 205, 297-304.

Siddons RC, Paradine J, Gale DL \& Evans RT (1985) Estimation of the degradability of dietary-protein in the sheep rumen by in vivo and in vitro procedures. Br J Nutr 54, 545-561.

Spencer D, Higgins JTV, Freer M, Dove H \& Coombe JB (1981) Monitoring the fate of dietary proteins in rumen fluid using gel electrophoresis. Br J Nutr 60, 241-247.

Stewart CS, Flint HJ \& Bryant MP (1997) The rumen bacteria. In The Rumen Microbial Ecosystem, pp. 10-72 [PN Hobson and CS Stewart, editors]. London: Blackie Academic \& Professional.

Theodorou MK, Merry RJ \& Thomas H (1996) Is proteolysis in the rumen of grazing animals mediated by plant enzymes? Br J Nutr 75, 507-510.
Thomas H (1978) Enzymes of nitrogen metabolism in detached leaves of Lolium temulentum during senescence. Planta 142, 161-169.

Thomas H (1997) Chlorophyll: a symptom and a regulator of plastid development. New Phytol 136, 163-181.

Wallace RJ \& Cotta MA (1988) Metabolism of nitrogen containing compounds. In The Rumen Microbial Ecosystem, pp. 217-249 [PN Hobson, editor]. Amsterdam: Elsevier.

Wallace RJ, Atasoglu C \& Newbold CJ (1999) Role of peptides in rumen microbial metabolism-review. Asian-Austral J Anim Sci 12, 139-147.

Wallace RJ, Newbold CJ, Bequette BJ, MacRae JC \& Lobley GE (2001) Increasing the flow of protein from ruminal fermentation - review. Asian Austral J Anim Sci 14, 885-893.

Zhu W-Y, Kingston-Smith AH, Troncoso D, Merry RJ, Davies DR, Pichard G, Thomas H \& Theodorou MK (1999) Evidence of a role for plant proteases in the degradation of herbage proteins in the rumen of grazing cattle. J Dairy Sci 82, 2651-2658. 